\title{
The Kingdom of God in the Gospel of Matthew
}

A B du Toit

(University of Pretoria)

\section{ABSTRACT}

\section{The Kingdom of God in the Gospel of Matthew}

It would be entirely wrong to regard "kingdom of God" as the central motif of the New Testament. Matthew's kingdom depiction should be read against the backdrop of a (mainly) Jewish Christian community in the process of re-defining its own identity over against Jewish opposition, which was consolidating itself under Pharisaic-scribal leadership. The genitive "of God/of heaven" signifies the kingdom as God-determined, but God's transcendence is mitigated by Matthew's portrayal of him as the Father of believers. Kingdom of God/heaven is a dynamic concept indicating God's active reign. The rule of God and righteousness, as its human correlate, are the key motifs in the Sermon on the Mount. Although the kingdom in Matthew involves a critical decision and the acceptance of strict entry requirements, it is not an entirely ethical concept, as is shown by the first beatitude. A growing correspondence between the kingdom motif and messiah christology can be traced. Modern churches in the process of losing their identity can benefit from a responsive reading of Matthew's kingdom message.

\section{INTRODUCTION}

The encounter between God and man, as reflected in the Bible, is so allencompassing that it cannot be compressed into the semantic scope of one single term. Moreover, the suitability of terms is not only limited by their range; it also varies according to targeted readerships. Therefore it is extremely hazardous to try and identify a single central motif in the Bible, or even in the New Testament. Whereas, for instance, the covenant motif fulfils an important role in the Old Testament, this is not the case in the New Testament. It certainly is not unimportant to the New Testament writers, but most of them prefer other terms, more suitable to their needs. In fact, the covenant metaphor appears in only 11 of the 27 New Testament books and only Hebrews employs it extensively. It would therefore be entirely wrong to view the covenant idea as the central motif of the New Testament.

The same is true for the term "kingdom of God", although this metaphor is far more prominent than the covenant idea in the New Testament. Joubert (1993:91-92) aptly calls this metaphor "a master symbol of the new reality" and correctly identifies it as belonging to the core of the message of the historical Jesus. This explains why it is so 
pervasive in the synoptic gospels. However, this is not valid for the Gospel of John, where it occurs only twice (3:3,5; cf 18:36). Paul also uses it quite sparingly. It occurs only 8 times in his undisputed letters. It certainly is not one of his preferred terms. Whereas it would not be wrong to call the kingdom one of the major New Testament themes, it should not be regarded as the central New Testament theme.

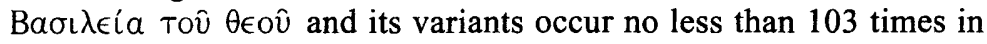
the synoptic gospels, as well as 8 times in Acts. The major importance of the kingdom message in the preaching of Jesus, as well as in the synoptic gospels and Acts, is one of the features which distinguishes Early Christianity from Ancient Judaism. The concept of the "kingdom of God/heaven" certainly occurred in contemporaneous Jewish writings (cf e g Kuhn 1957:570-573; Schmidt 1957:573-576; Duling 1992:51-54), but nowhere did it occupy a major role (Lindemann 1986:196,200).

Of the 103 occurrences, 50 are found in Matthew, 14 in Mark and 39 in Luke. In terms of relative length (Matthew counts 1068 verses, Luke 1149), Matthew uses the term significantly more than Luke, and he certainly attaches no less theological significance to it. This makes Matthew the New Testament writer who makes the most profound use of the kingdom idea.

\section{MATTHEW'S KINGDOM PRONOUNCEMENTS WITHIN THE SETTING OF HIS GOSPEL}

Matthew's message of the kingdom of God did not take place in a vacuum. It was targeted at the specific needs of his audience.

The "Jewish" character of Matthew's gospel has often drawn attention. This is evident from, inter alia, the many quotations and allusions from the Old Testament, the Hebrew/Aramaic expressions which were left untranslated (e g raka in 5:22; korban in 17:6 - cf Mk $7: 11$, where a translation is provided), his positive attitude towards the law (cf 5:17-18), his emphasis on righteousness (e g 3:15; 5:6,10,20; $6: 1,33$ etc), his special attention to Israel $(10: 5-6 ; 27: 25)$, his portrayal of Jesus as the expected Messiah (1:1-17 etc), and his respect for Jewish sensitivities as illustrated, for example, by his use of the divine passive (e g 5:4,6,7,9). These and many more features indicate that the writer is a Jewish Christian, writing to mainly Jewish Christians. He writes, from somewhere in Syria or the adjacent Upper Galilee (see the extensive discussion in Balch, 1991), to fellow Jewish Christian compatriots who are experiencing growing opposition from neighbouring Jewish communities. In the period after the fall of Jerusalem in $70 \mathrm{AD}$, an increasing separation between church and synagogue took place, eventually culminating in the birkat ha-minim (approximately $85 \mathrm{AD}$ ), in which God's curse was invoked on all apostates, especially on Jewish Christians. This effectively resulted in the exclusion of the latter from worshipping in the 
synagogue, although with some exceptions (Segal 1991:35). They were vilified as breakaway renegades who subverted the law. They found themselves in the predicament of a young movement, positioning themselves alongside Judaism, differing from it in their Jesus belief and its implications, but still holding to many of the main Jewish tenets. Their problem was one of redefining their own identity in the face of a hostile Jewish community, which was in the process of consolidating itself under Pharisaic-scribal domination (cf Johnson 1986:176-177). The implications of this scenario were twofold:

Positively, Matthew had to give his readers spiritual encouragement. Moreover, they needed to rediscover their own identity. An identity crisis inevitably involves a crisis of survival. When a faith community's religious universe is not well-defined; when its codes of belief and conduct have become blurred; when it lacks clearly demarcated borders and entrance requirements; when its inner discipline has become lax, the centripetal forces binding its adherents together, inspiring them and motivating them, are lost and disintegration knocks at the door. It becomes a "character-less", spineless, purposeless entity like the "saltless salt" of Matthew 5:13. At least some of Matthew's aims in writing his gospel were, not only to strengthen the spiritual disposition of his church, but also to assist his readers in rediscovering their true identity (cf White 1991:238-9). He wanted them to realise their high status: they are the blessed ones to whom the kingdom belongs; as opposed to Jewish self-consciousness, they should realise that they are the new and true Israel of God (Trilling). However, at the same time, they should live up to this status. They should exhibit the "exceeding righteousness" in their daily living. There are indications that they were not doing this. They seem to have lapsed into various kinds of spiritual slothfulness (Kingsbury 1969:135; Luz 1985:72). This had to be countered by reaffirming and stressing the demands of the kingdom.

Negatively, these Christians were to be strengthened against the accusations, attacks and even persecutions (5:10-12,44; 10:17-39; 13:21; 23:34-36) on the part of their Jewish adversaries (see Kingsbury 1969:58-60, who sees the persecution as coming from both Jews and gentiles, but concedes that the former dominated). Seen in this light, the scathing criticism of the scribes and Pharisees, who sit on the seat of Moses but do not practise what they preach (23:2-3), becomes more understandable (John the Baptist: 3:7-10: Jesus: 5:20; 12:34-36; 15:14 and especially chapter 23; cf further 7:29 and Matthew's depiction of them as Jesus' adversaries).

The implications of this setting will hopefully become clearer in what follows. At this stage, I only wish to point out the fact that the Jewish setting of Matthew's gospel explains his insistence that Jesus did not come to abrogate the law, but to fulfil it (5:17-19). Although the 
followers of Jesus should not conform to the ways of the scribes and Pharisees, they should nevertheless obey their instructions (23:3). In fact, Jesus even wanted his people to surpass the righteousness preached and practised by the Jewish religious leaders by obeying the deepest intent of the Lawgiver (5:21-48).

The Jewish setting of Matthew also explains his preference for the term "kingdom of heaven" rather than "kingdom of God". Whereas Mark and Luke, who wrote for non-Jewish Christians, consistently uses the latter, Matthew uses "kingdom of heaven" 32 times, the genitive $\tau \hat{\omega} \nu$ oujpav $\hat{\omega} \nu$ being a typically Jewish reverential periphrasis for the divine name. An alternative understanding of the qualification "of heaven" might be that Matthew wanted to stress the absolutely incomparable, transcendent, cosmic-universal character of the reign of God in contrast to other, "earthly" ones (cf Lindemann 1986:209). This may have played a subsidiary role anyway, but the prevalent view that "of heaven" is primarily a circumlocution for God, seems more convincing. As was the case with the passivum divinum, our evangelist did this in light of the sensitivities of his Jewish readers. That he himself experienced no scruples in this regard, is indicated by his occasional use of "kingdom of God" (12:28; 19:24; 21:31,43; probably also 6:33). Pamment (1981) is of the opinion that Matthew uses the term "kingdom of God", in contrast to "kingdom of heaven", whenever he refers to the presence of the kingdom. However, the saying about the men of violence (11:12), where "kingdom of heaven" obviously refers to a present reality, contradicts this. Thomas (1993) advocates the interesting view that Matthew uses "kingdom of God" as a literary device intended to focus the attention of his readers on concerns of particular importance to them. However, this issue has not yet been settled.

We can now proceed to explore the main contours of Matthew's kingdom preaching.

\section{THE FORGOTTEN GENITIVE}

It is remarkable how often reflections on the kingdom of God in the New Testament simply ignore the importance of the qualifying genitive "of God". Moreover, this is not simply a possessive genitive or a genitive of origin; it is subjective, indicating that God is actively at work here. It therefore qualifies the kingdom as God-centred, as God-determined, as the product of God's personal being and activity.

In his magisterial book on the coming of the kingdom, Herman Ridderbos (1950) sees and accentuates the theocentric character of the kingdom of God very clearly. For instance he declares categorically: "Daarom is de idee van de komst van het koninkrijk vóór alles: die van de koninklijke zelfhandhaving Gods, van de realisering van zijn rijk, van zijn komen tot de wereld om Zich in zijn koninklijke majesteit, kracht en 
koninklijke recht te openbaren" (1950:36). This insight implies the rejection of every kind of anthropocentric or humanistic approach to the New Testament message of the kingdom (Ridderbos 1950:37).

The God-determined character of the kingdom implies that believers' God-experience also influenced perceptions of the kingdom. In the first century Jewish image, he was first and foremost the holy, distant God who lived in heaven. There was, for example, a marked hesitancy to refer to God as Father (cf Jeremias 1971:68-72). Thus, the "kingdom of God" was also predominantly experienced as distant and wholly transcendent. Without doubt, a strong element of this "otherworldliness" is also inherent in Matthew's understanding of the kingdom. But, at the same time, the Fatherhood of God plays a more dominant role in Matthew than in the other gospels (see e g Jeremias 1971: 174-180). This brings connotations of love, warmth and closeness into Matthew's kingdom concept. In Jesus' kingdom saying in Matthew $13: 43$, this becomes quite clear, since the royal and family metaphors are here so closely associated: "Then the righteous will shine like the sun in the kingdom of their Father." This combination of the holiness and the love of God, of his transcendence and his nearness, are also evident in the expression "your Father in heaven/your heavenly Father" (Mt 5:16, 45,$48 ; 6: 1,11$ etc). In the same vein, the Lord's prayer starts with the appellation: "Our Father in heaven", thus encompassing both aspects. This meaningful, contrapolar union of God's holiness and love can be called typical of Matthew's concept of God and therefore also of his view of the kingdom.

Another feature of the God-determined character of the kingdom is its cosmic scope: God is the Creator, the horison of his kingdom is cosmic in character. The coming of the kingdom is not merely directed towards saving souls for heaven. In the Sermon on the Mount the righteousness required of the citizens of God's kingdom covers the totality of human existence. And in the concluding verses of Matthew, Jesus speaks as the mighty King whose authority covers the entire universe, and whose commission encompasses "all nations" (Mt 28:1920).

In this context, the notion of the growth of the kingdom requires our attention. Kingsbury (1975:146) correctly indicates that, in Matthew, it has nothing to do with the "old liberal idea that the Kingdom is a social, moral or spiritual force that will gradually spread throughout the world as it captures the hearts of people". Contrary to this humanisticevolutionistic idea, the growth of the kingdom, as vividly pictured in the parables of the mustard seed and the leaven (13:31-33), remains primarily an action of God, the Lord of heaven and earth (11:25), who expands his kingdom through the proclamation of the gospel, first through Jesus and his pre-Easter followers, and thereafter through the post-Easter 
church $(24: 14 ; 26: 13 ; 28: 18-20)$. The miraculous growth of the kingdom takes place wherever people from all nations acknowledge and bow under the rule of God. Thus, the inclusive, cosmic dimension of the kingdom becomes apparent. But even so, no straight line can be drawn from the impressive growth of the kingdom to the final consummation. At the end of history, God will still have to intervene, by means of the parousia of his Son, to bring about the consummation of the kingdom.

Other characteristics of the kingdom, such as its dynamic character, its eschatological nature, its promise and its demand, all basically derive from, and are qualified by, its theocentric character. However, we shall discuss these aspects from various other angles.

\section{THE DYNAMIC NATURE OF THE KINGDOM}

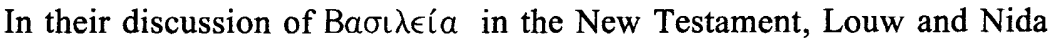
make the following significant observation:

"It is generally a serious mistake to translate the phrase

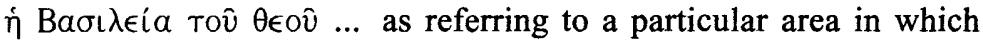
God rules. The meaning of this phrase in the New Testament involves not a particular place or special period of time but the fact of ruling. An expression such as 'to enter the kingdom of God' thus does not refer to 'going to heaven' but should be understood as 'accepting God's rule' or 'welcoming God to rule over'..." (Louw and Nida 1988 I: 480).

This may be an overstatement, but it seems basically correct (for different views, see Duling 1992:50,62-63). In terms of traditional grammar, the abstract noun $\beta \alpha \sigma \iota \lambda \epsilon i \alpha$ should be understood as a nomen

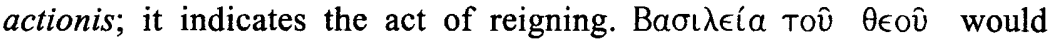
therefore be best translated as the "reign of God" or "God's kingly rule" (in German: Gottes Königsherrschaft). To be true, we find many instances where a reference to the kingdom is preceded by a preposition of locality, such as "in the kingdom" $(5: 19 ; 8: 11 ; 13: 43$ etc) and "to enter into the kingdom". Here we definitely have some notion of locality and, in this sense, Luz (1980:485) and Lindemann (1986:200) are correct. Yet even so, the prepositions refer to "being in" or "entering into" the sphere where God reigns. God's reigning activity is always dynamic and even the sphere of this activity is never static. "Kingdom of God" indicates God's active reign. Or, put differently: it implies the active realisation of God's will. In the same vein, the second petition in the Lord's prayer, viz that God's kingdom should come, is immediately followed by the prayer that his will should be done. Lindemann points out that Matthew has added the third petition in comparison to $Q$. Accordingly, he views the prayer that God's will be done as a Matthean addition, intended to concretise the petition for the coming of the kingdom (1986:209). 
Matthew calls the obedient realization of God's will by human

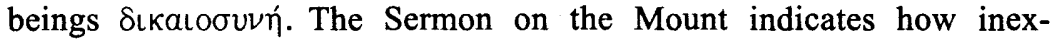
tricably God's reign is interwoven with "righteousness" (kingdom: $5: 3,10,19,20 ; 6: 10,33 ; 7: 21$; righteousness: $5: 6,10,20 ; 6: 1,33)$. The "rule of God" and "righteousness", as its human correlate, are in fact the two key concepts in the Sermon on the Mount. That they intrinsically belong together, is especially clear from 6:33, where "righteousness" is an attribute of the kingdom, and seeking the kingdom and its righteousness is depicted as the highest priority of our existence.

\section{THE ESCHATOLOGICAL CHARACTER OF THE RULE OF GOD}

The cultural optimism of the late nineteenth and early twentieth century resulted in various forms of liberal theology, each casting the kingdom in an entirely immanent, evolutionistic mould. Ritschl, for instance, expected that the kingdom would realise itself in the moral transformation of humanity. Theologically, it needed the critical insights of Johannes Weiss (1946 [1892]) and the persuasive force of a colossus like Albert Schweitzer (1966 [1906]) to crack this mould. Socially, politically and ideologically, it took the atrocities of two world wars, catastrophies like the genocides in Eastern Europe and Africa, and the aids pandemic to finally break this naïve optimism.

On the New Testament front, Cullmann (1948; 1965), in particular, took up, criticised and qualified the insights of Schweitzer regarding the futuristic, unrealised character of Jesus' kingdom message, on the one hand, and on the other, the insights of $\mathrm{C} \mathrm{H}$ Dodd, who championed what he called a "realised" eschatology (Dodd 1961 [1935]). Cullmann insisted that the New Testament authors reflect an intermediate position between Schweitzer's consistent and imminent, essencially unfulfilled eschatology and Dodd's realised eschatology. This intermediate position, which he qualified as the tension between the "already" and the "not yet", has gained world-wide recognition, although his insistence on the salvation-historical character of biblical thinking has been criticised by some. Cullmann clearly indicated how all the New Testament writers believed that, in Jesus Christ, in his preaching, and in his life and death, the kingdom had already manifested itself in history, although its final consummation would only take place in the future. We have already seen that the New Testament, and especially the synoptic gospels, differed from contemporaneous Judaism in the central importance attached to the kingdom message. What makes the New Testament message even more decisively different from Judaism, and in fact from all other beliefs, is the conviction that, in Jesus, God's kingdom has arrived among men and that the "coming age" was already at work in the midst of the present. The idea of the presence of God's reign was not entirely alien to Jewish 
groups during the first century (see Lindeman 1986:196-200). However, nothing can be found elsewhere which even approximates the strong sense of fulfilment, which pervades in the New Testament. Although this presence of the kingdom was in many ways inconspicuous, "hidden", it could be perceived by the eyes of faith.

Within the basic parameters of the "already" and the "not yet", we should, of course, allow for varying insights and emphases amongst the New Testament writers. We know, for instance, that John, with a view to the needs of his readers, accentuates the "already" much stronger than the "not yet". However, even he does not abandon the latter (cf e g Cullmann 1965:265-267).

Matthew also moves within these parameters. His conviction of the "already fulfilled" aspect of the Christian message is obvious in his many Old Testament quotations, claiming time and again that, in Jesus Christ, the Scriptures have been fulfilled $(1: 22 ; 2: 15,17,23 ; 4: 14 ; 8: 17$ etc; cf also Combrink 1983:79-80). Due to the lack of sufficient linguistic indicators, the debate as to whether the perfect $\eta \eta \gamma \gamma \iota \kappa \in \mathcal{V}(\dot{\eta} \beta a \sigma \iota \lambda \in i a$

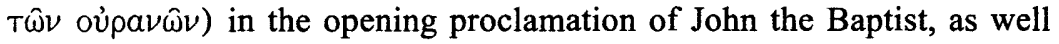
as that of Jesus and his disciples, which Matthew deliberately parallels (cf Mt 3:2; 4:17 and 10:7), should be understood in the sense of "has arrived", "is here" (Dodd) or, as most understand it, in the sense of "is near", "at hand", will probably never be settled. Van der Walt's (1962:198) view that this perfect form deliberately cuts both ways, may be on target. Be that as it may, in Matthew 12:28, which Matthew has taken from Q (cf Lk 11:20), the presence of the kingdom is indisputable: "But if it is through the Spirit of God that I cast devils out, then the reign of God has come upon you". This was in contrast to contemporary Jewish thinking, which saw the kingdom as a still outstanding, eschatological reality. Jesus' victory over the demons is a clear sign that God's rule was working in and through his person. The presence of the kingdom is also apparent in Matthew 11:12. In spite of a wide range of views

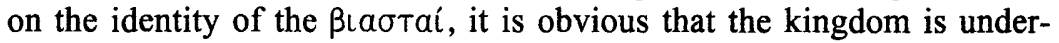
stood as being present (cf also Luz 1980). Sayings like Matthew 12:41f; 13:17, where the decisive significance of the Jesus event is highlighted, also fit into this picture. In several parables, the presence of the kingdom is assumed. This is the case in the parables of the sower (13:3-23), the twin parables of the hidden treasure and the costly pearl (13:44-45), those of the mustard seed and the leaven (13:31-33), the fishing net $(13: 47-50)$, and others. The first and the eighth beatitude refer to the kingdom as a divine gift that belongs to the "blessed" already here and now, although its consummation lies in the future.

Also with regard to the "not yet" aspect of the kingdom, Matthew agrees with the rest of the New Testament. In Matthew 8:11 and 26:29, the well-known metaphor of the eschatological banquet is used to 
portray the future bliss at the consummation of the kingdom. In the second petition of the Lord's Prayer, the coming of the kingdom is also seen as a future event. Although there is only one reference to the kingdom of God in the eschatological discourse (Mt 24), viz in the phrase "the gospel of the kingdom" (24:14), the consummation of the kingdom is certainly envisaged as a future event. Parables like that of the weed among the wheat (13:24-30,36-43), the dragnet (13:47-50), the labourers in the vineyard (20:1-16), the marriage feast (22:1-14), the servants waiting for their master (24:45-50), and the ten maidens (25:113) are double-edged, in the sense that they move from the "already" to the "not yet". In fact, the coming of the kingdom is, in fact, understood as one momentous event, manifesting itself in two phases. Van der Walt (1962:33-179), especially, identifies the intrinsic bond between the different "comings" of the kingdom. He indicates how this is undeniably illustrated by the "Son of Man" sayings, which bind together the earthly, historical presence of Jesus and his future coming.

Regarding the imminence of the consummation, we find several indications that Matthew was reckoning with the problem of a longer than expected interim period. This is quite clear from the parables in which the need for prolonged watchfulness, preparedness and diligence is stressed (see 24:45-51;25:1-13,14-30) i e cf Mk 13:32). With the statement that the gospel must first be proclaimed in the whole world before the end will come (24:14; of Mk 13:10), Matthew provides his readers with a thoroughly pastoral answer. As a good pastor he is gently shepherding his readers towards coping responsibly with one of the problems for which the church of the outgoing first century needed an answer (cf also 2 Pt 3:8-10). As in Mark (13:32), the problem regarding the delay of the parousia is mitigated by the Jesus saying that (even) the Son does not know the specific day and hour; it is the Father's prerogative (Mt 24:36).

Modern western thinking does not find the apocalyptic worldview of the New Testament very congenial. However, the apocalyptic-eschatological understanding of Jesus' message is an integral part of the New Testament message. In fact, this conviction holds the only real key towards the final deliverance of mankind and the cosmos. Therefore, we have to endorse it in its full tension between the "already" and the "not yet". In no way should we slacken this tension. To deny the "not yet", as is done for example in the social gospel and in the various historical manifestations of the corpus christianum idea, is a humanistic deception, underestimating the reality of human sin and frailty. It implies the hoping for an illusionary utopia. Should we, on the other hand, dissolve the "already", it could imply a denial of what the New Testament saw as the turning point of history. If we may use a metaphor of Cullmann: it would be to deny that the decisive battle has been won in Jesus' death 
and resurrection, and that only "victory day" still has to dawn. It would be a denial of God's "yes" to his creation. It would imply that we should follow the route of withdrawal from the world, because Satan still lords over it. That could not only be thoroughly uncalvinistic; it would also be thoroughly unbiblical.

\section{THE CRITICAL DECISION}

The coming of the kingdom signified a crisis. It challenged people to make an existential decision. This is clear from the preaching of John the Baptist as well as that of Jesus $(3: 1-12 ; 4: 17)$. Those who repent and live accordingly, will receive the bliss of the kingdom (cf 5:3-12). However, the choice for the kingdom is not easy. The man, who finds the treasure in the field, has to sell "all that he has" in order to obtain the treasure (13:44). The same is required of the merchant who wants to make the "pearl of great value" his own (13:45). It requires entering the "narrow gate" and walking the "hard way" (7:13-14), paying the price of discipleship (see especially $8: 18-22 ; 10: 34-39)$. It requires becoming a servant to others $(20: 25-28)$.

On the other hand, those who refuse to repent, will have to reckon with the wrath of god $(3: 7,12)$. On judgement day, the son of man will call them the "accursed"; they will experience "eternal punishment" $(25: 46)$, the "fiery furnace" $(13: 42 ; 25: 41)$, the "outer darkness" (8:12) (Kingsbury 1975:148).

This crisis was not limited to individuals. The future of Israel was at stake. Israel's decision against Jesus implied that the kingdom was taken away from them and given to the nations $(21: 43$ cf $8: 12 ; 28: 18-$ 20).

\section{ENTRANCE REQUIREMENTS}

As we have already indicated, repentance is an essential requirement for inheriting the kingdom. But this implies an inner conviction about the overriding importance and extreme value of the kingdom. This aspect is highlighted by the two striking parables of the treasure in the field and the pearl of great value (13:44-45). This is also expressed in plain speech in the summons to seek first the kingdom and its righteousness (6:33). For the rich, the choice between their earthly possessions and the kingdom may prove to be too difficult - as illustrated by the striking metaphor of the camel trying to go through the eye of a needle (19:23-24; cf 19:16-22).

In this regard, the inner disposition required of those who will inherit the kingdom is also relevant. Especially important are certain Matthean passages referring to children (Mt 18:1-5; 19:13-15; 21:15-16 cf 11:25-27) and the first beatitude (5:3), since they reflect an important concern of Matthew, as of Jesus himself. In Matthew 19:14, Jesus states 
that the kingdom of heaven belongs to the children. The motivation for this weighty pronouncement would certainly be the trusting, open, dependent, humble, spontaneous attitude of small children. In 18:1-5; 19:13-15 and 21:15-16, real children are being pictured. However, Jesus' emphasises in 18:3 (cf also 18:4) that only those who change and

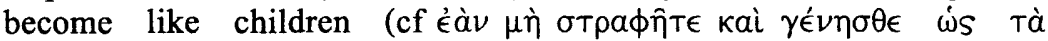

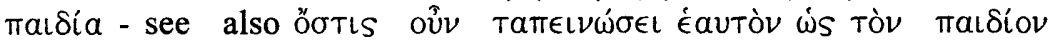
ToûTo - v 4) will enter the kingdom (which is missing in both mark and Luke). It is therefore clear that Matthew wishes to stress this child-like attitude as a universal entrance requirement (see also Luz 1997:115). Likewise, in Matthew 11:25, "these things" were hidden from the wise

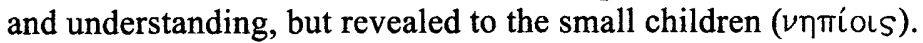

The first beatitude makes a similar point, although using a different metaphor. The correspondence between Matthew 5:3 and 19:14 is striking, the only difference being that, in the former, the kingdom belongs to the "poor in spirit", while in the latter it belongs to the children. The significance of the first beatitude is reflected in its position. As such, it qualifies the rest of the Sermon on the Mount. Matthew uses the Greek word $\pi T \omega \chi$ ós, which most probably refers to the very poor, the destitute (German: bettelarm), in contrast to the $\pi \epsilon ́ \nu \eta S$ who is also a poor person, but can still cope somehow by living sparingly (cf Louw and Nida $1988 \mathrm{i}: 564$ ). The rule of thumb in understanding the difference between these two words is: the $\pi \epsilon \operatorname{\eta \eta }$ must work, the $\pi T \omega x$ ós must beg (Luz 1985:204).

It has often been said that Matthew tends towards being a gospel of good works. However, the first beatitude (as well as Matthew's depiction of the salvivic meaning of Jesus' life and death) disproves this view. In Matthew 5:3, the kingdom of heaven is an undeserved gift, granted to those who know that they have nothing to offer him and therefore depend absolutely on him. This certainly does emphasise good works. Therefore, it is misleading when Luz (1985:207) finds a tendency towards ethicising in the first beatitude. If one followed Luz, it would only be logical to also draw faith into the ethical sphere. On the other hand, Matthew also insists that entrance into the kingdom will be denied to those whose acceptance of the kingdom is not manifested in their lifestyle. This is already clear from the obvious ethical dimension in the beatitudes following on the first $(5: 4-12)$. It is in this sense that righteousness is also an entrance condition (5:20).

The enquiring modern mind, steeped into accepting only what can be proven scientifically, finds it increasingly difficult to accept that the kingdom can only be entered after becoming children again. It associates this notion with being naïve, with uncritically accepting all kinds of superstitious beliefs. One of the daunting tasks of Christian apologetics would certainly be to convince modern man that the kingdom message in 
no way obstructs scientific enquiry and, in fact, encourages believers to engage in scientific efforts aimed at understanding and serving our world and its best interests. At the same time, the spiritual character of the kingdom should also be explained. Faith is not a-scientific, but it functions - qua its essence - in a different sphere. The key to this sphere, as Matthew reminds us, is given to those who, despite their purported intellectual coming-of-age, are prepared to trust the king of the kingdom like a child accepting the integrity of his/her father.

\section{THE KINGDOM AND JESUS MESSIAH, THE SON OF GOD}

Within the context of Matthew, it is clear that the kingdom is ushered in by the person and activity of Jesus. This is quite clear from Matthew $12: 28$, where the presence of the kingdom is demonstrated by the exorcist activity of Jesus. He raids the kingdom of Satan (11:25-28), binds the "strong man" (11:29), and plunders his house. It is through him that god comes with his rule and that this rule is obediently acknowledged (Kingsbury 1975:140). He is indeed the autobasileia.

The Christological title "the son of man" is most intimately connected with the kingdom motif, like the title in the book of Daniel. However, the question is whether a kingly Christological title like that of messiah is in some way also connected to this motif. The importance of the messiah-title to Matthew is evident from its redactional nature in about two thirds of the 16 times (16:21 is text-critically dubious) it appears in Matthew (Kingsbury 1975:96). Traditionally it was accepted that first century Jewish messianic expectation was uniform and also political in nature. Recent study of Jewish sources has revealed that this is a misconception. There were various types of messiahs, depending on the circle within which a specific messianic expectation originated (de Villiers 1998:454-457). Some of these were politically coloured, others not. Therefore it would be wrong to accept, apriori, that the Jewish messianic expectation, which Matthew presumes, was of a political nature. We should consult his intra-textual indications in this regard. From the Matthean narrative itself, it is clear that the antagonists of Jesus viewed him as a political messianic pretender (Kingsbury 1975:97). King Herod certainly did, and therefore wanted to eliminate

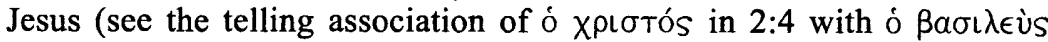
$T \hat{\omega} \nu$ 'Iov $\delta a i \omega \nu$ in 2:2). Also Pilate, the roman cohort and the Jewish leaders associated "messiah" with a political throne-pretender $(27: 11,17$, $22,37,42$ ). For Matthew, Jesus is indeed the messiah, as stated already in his opening genealogy (see especially $1: 16,17$ ). In Matthew 11:2-6, the enquiry of John the Baptist, who associates the messiah with the "coming one", is positively answered by Jesus (see further 16:20; 23:10; 24:5,23). However, Matthew emphasises that the Messiaship of Jesus is not political. In the confession of peter (16:16), he is the only evangelist 
who adds to the confession that Jesus is the Christ (= messiah), that he is "the son of the living god". Because "son of god" is a non-political title, Matthew purges the Messiaship of Jesus of any political connotation (cf Kingsbury 1975:97-98). This "confessional understanding" of who Jesus really is (Kingsbury 1975:idem), is so radical and of such cardinal importance that it can only be described as a revelation from god $(16: 17)$. We find an echo of this same messiah-son of god combination in the question of the high priest (26:63), but we should differentiate between the high priest's use of the sonship motif and Jesus' understanding of it. Van Aarde (1994:72), for example, understands the high priest's words as an example of irony.

We can now return to the matter of the relationship between Jesus as messiah and the kingdom motif. For Matthew, both are unpolitical concepts; in addition, both have kingship connotations. But this as such does not necessarily create a direct connection between them. However, we find some indications in that direction and, interestingly, these indications become stronger towards the end of Matthew. Immediately after Peter's confession of Jesus as messiah, the Son of God, Jesus promises him the "keys of the kingdom of heaven" (16:19). Jesus messiah, the Son of God, acts here as the designated new king of the kingdom, being granted this place by god (cf Lk 22:29). Matthew 18:18, which harks back to $16: 19$, should be understood against this background. This view is also corroborated by $16: 28$, where Jesus is depicted as the king of the kingdom, although the son of man title is used here (cf also Mt 13:41). The kingdom of Jesus is likewise evident in the request of the mother of the sons of Sebedee and Jesus' response (see 20:20-23). Most probably, the messiah, son of god combination - in addition to other motifs like that of the Emmanuel - plays an important role in the majestic words of the universal king to whom all authority in heaven and on earth belongs, and who commissions his disciples to go to all the nations $(28: 18-20)$. The kingship of Jesus, messiah, Son of God, now occupies centre-stage; the messiah designate has become king. From now on, the king of the kingdom is Jesus.

\section{KINGDOM AND CHURCH}

The complexities involved in the relationship between church and kingdom cannot be settled unequivocally. Like the kingdom, the church is obviously important to Matthew. This is indicated, not only by his great efforts to address the needs of his church(es), but also by the well-known

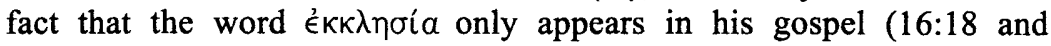
18:17).

It is intriguing to note that, in the wake of Peter's confession, "church" and "kingdom" are used in such close proximity (see 16:1819). In 18:17-18, we find this same association. Although the word 
"kingdom" as such is not used, the same idea of "binding" and "loosening" and the reference to heaven indicate that church and kingdom are closely related. The question is how?

That church and kingdom are closely related and overlap to an important extent, is evident from the conviction that exclusion from the church implies exclusion also from the kingdom (18:17-18). However, it would be wrong to see kingdom and church as identical. The decisive difference is that the latter is a concrete, earthly reality, albeit with spiritual dimensions. As an assembly of flesh and blood beings, it is empirically observable. The kingdom on the other hand, being the ruling activity of god, is essentially an abstract, heavenly, spiritual reality, but with earthly implications. It cannot be observed empirically, although its presence in the world, and the effects of that presence, can be recognised. However, this recognition is reserved for those whose eyes have been opened by the father (11:25-27; cf 16:17).

We can say that the church is the earthly manifestation par excellence of the presence of the kingdom. It is the place, first and foremost, where god's rule has been recognised and is obeyed. The church is an instrument of the kingdom. It is to the followers of Jesus - the church that the message of the kingdom is entrusted. Yet the church is not entirely the kingdom in action. We can pray "let your kingdom come"; we cannot pray "let your church come". Jesus promised the kingdom to the poor in spirit; he would not promise them the church. The church, in spite of its eschatological character, is still an earthly entity, open to human sin and frailty. While we could speak, in a salvation-historical sense, of the "not yet" of the kingdom, we could not say the same of the church, since the church, in spite of its many defects, is already fully present. The kingdom is also much wider than the church. The kingdom of the son of man in Matthew 13:41 has cosmic dimensions (cf also 11:25). The church consists only of the concrete Jesus community.

\section{LIFE IN THE KINGDOM - THE ETHICAL ASPECT}

To view the kingdom as entirely ethical like Ritchl did, is certainly unwarranted. However, Matthew makes it clear that the kingdom has very distinct ethical implications. The indicative of the kingdom calls forth the imperative. In the Sermon on the Mount, the first beatitude presents the indicative, and the following eight display a strong ethical slant. From 5:13 onwards, the ethical demand of the kingdom is even more apparent.

Where the beatitudes portray the bliss and identity of the citizens of god's kingdom primarily in relation to god, Matthew 5:13ff depicts their identity and code of conduct in relation to the world. Within the larger context of Matthew 5:13-7:29, and especially 5:13-48, 5:13-16 forms a thematic heading which summarises the task and the identity of 
the Jesus people by means of four striking metaphors: that of the salt; the light; the city on the mountain; and the lamp. In this context, the task of Christians is depicted, not in terms of their oral witness, but in terms of the quality of their being in the world - their concrete life-style. If they lived true to their identity, god would be glorified. If they lost their identity, they would be trampled upon (= treated by contempt) by the of ả $\nu \theta \rho \omega t r o l$ (see du Toit 1966; 1981:174; cf also Lippert 1968:175). Matthew formulates the life style required of Christians as the righteousness, which exceeds that of the scribes and Pharisees (5:20). The content of this righteousness is explicated by means of six antitheses (5:21-48). With his "but I say unto you" Jesus internalises and radicalises the demands of the old testament laws over against the contemporary minimalising and exteriorising contemporaneous interpretations. In the case of the last three, he even contradicts the surface expression of the Mosaic Law by disclosing the deepest intent of the lawgiver (du Toit 1977:42-43). In the concluding and climactic last antithesis $(5: 43-48)$, the very essence of this righteousness is reflected: it is the inclusive, limitless love.

It is this "exceeding righteousness", this qualitative "over and above" ( $\pi \epsilon \rho \iota \sigma \sigma o ́ v$ - 5:47) which should characterise the conduct of the citizens of the kingdom, and therefore also that of the Matthean community. It is this very special life-style which will demonstrate that they are a very special community and that they are serving a very special god. This will induce the outsiders to glorify god (5:16). The ethical demand of the kingdom is further explicated in Matthew 6-7. The Sermon on the Mount concludes with a strong affirmation of the necessity for obeying god's will. The false prophets will be recognised by the wrong fruit, that they bear, while Jesus' followers will be recognised by their bearing the right fruit (7:15-20). To address Jesus as lord is not enough; the decisive requirement is doing the will of the father (7:21-23). Doing the words of Jesus is as essential as hearing them (7:24-27). It is the doing of Jesus' commands, which gives the rock-like firmness to the life of his people. It is the doing of god's will which constitutes the difference between false and true prophets, bad and good trees, a house on the sand and a house on the rock (Combrink 1983:59-60; cf also 95-98). This focus on the necessity of doing god's will, pervades in the whole of Matthew. Those doing the will of Jesus' father in heaven, is his family (12:48-50). In the parable of the two sons $(21: 28-32)$, the decisive criterium is who "did the will of the father" (v 31). The new people of god are characterised as doing the fruit of the kingdom (21:43). The scribes and Pharisees are castigated because they preach but refrain from doing (23:3). According to the words of the departing Jesus, true discipleship consists in the observance of everything he has commanded (28:19). If our surmise is correct that the church which Matthew addressed showed signs of ethical 
laxness, this would explain Matthew's heavy accent on obedience to god's will.

In order to do the will of god, it is necessary to know it. For that purpose, teaching is necessary. This is perhaps the main reason why the $\delta\llcorner\delta a ́ \sigma \kappa \omega$ word-group is so prevalent in Matthew (cf i e 4:23; 5:2,19; $7: 28-29 ; 9: 35 ; 11: 1 ; 28: 20)$, and why it is often called the "teaching gospel".

One remaining aspect of the kingdom's demand still requires attention: the task of proclaiming the gospel of the kingdom. According to Matthew, both John the Baptist and Jesus started their preaching by announcing the coming of the kingdom $(3: 2 ; 4: 17)$. In the sending out of the twelve, the disciples are commissioned to make the same announcement (10:7), thus becoming an extension of Jesus' own activity (Kingsbury 1975:129). In Matthew 4:23 and 9:35, "preaching the gospel of the kingdom" is placed midway between the teaching and the healing activity of Jesus, indicating that "preaching the gospel of the kingdom" is Jesus' central activity, and that it consists of teaching and healing. In Matthew 24:14 and 26:13, proclaiming the "gospel of the kingdom" refers to the preaching of the post-Easter church. Matthew, therefore, sees a direct continuation of the work of Jesus in the task entrusted to his

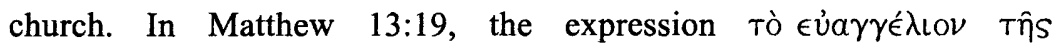
$\beta a \sigma i \lambda \epsilon i a s$ is replaced by ó $\lambda o ́ \gamma o s$ Tn̂s $\beta a \sigma \iota \lambda \epsilon i a s$, and in the following verses simply by $\lambda$ ó $\gamma 0 S$ ( $v 20-23$ ). In this parable and its explanation $(13: 3-23)$, it becomes clear that the preaching of the gospel calls forth various reactions from the hearers. But it also calls forth opposition from Satan (v 19). Satan has his own kingly rule (12:26). This rule encompasses "all the kingdoms of the world and their glory" (4:8-9) and it stands in unmitigated opposition to the kingdom of god. It comes into action not only when the kingdom breaks into the world in the person of Jesus (4:1-11), but also wherever the kingdom message is being preached (see especially Kingsbury 1975:149-152). Nevertheless, the task of proclaiming the kingdom should continue until its final coming. In the final analysis, the promise of the great sower, regarding the prolific multiplication of the seed falling in the good soil, makes all the effort worthwhile $(13: 8,23)$.

\section{CONCLUSION}

It is a commonplace, if not an understatement, to postulate that many churches today are in a state of decline. Many reasons for this could be advanced. Nevertheless, one of the main causes of this sad situation would certainly be the loss of a sense of identity. This, in turn, is to a large extent due to uncertainty about the "fundamentals" of our Christian faith. So many of these basic beliefs have been challenged by a secularistic environment, and often even by theologians themselves, that our 
basic set of convictions has become blurred. We have lost sight of the wholly otherness of the kingdom of god and the god of the kingdom. We have forgotten the radicality of the kingdom offer, its joy, and its liberational character. We certainly have lost sight of the radicality of its demand. The result is that many churches have lost their salt; they are always on the retreat; they try to keep their members by means of people-friendly strategies - which, as such, is not wrong -, but without realising what people really need, and have needed through all the ages, is the treasure in the field, the pearl of great value: the liberating, joyful and life-changing message of the kingdom. Strange as it may seem, it is not the lowering of kingdom standards, which attracts people, but their upholding. When Christian communities possess and experience a clear sense of identity; when their convictions, vision and mission are well demarcated; when their entry requirements are demanding and respected; when there is a close bond of real Christian love and caring between group members, they experience a sense of home-coming, of belonging and they develop an urgency to fulfil their mission.

We should never lose sight of the momentous character of the Christ event, which changed history forever and made this life worth living. Otherwise, Christians would have to become mere otherworldly beings, emaciated souls longing for heaven. This kingdom is theocratic and dynamic in character. It has a cosmic scope, and although it is not a political entity as such, it has thoroughgoing implications for politics, social behaviour, and the economy - for all fields of human endeavour. The kingdom is present; through the being and witness of Christians it should radiate its influence over the entire world. Inherent in the kingdom message is dynamic forces, able to transform the world.

Likewise, we should also never lose our vision of the consummation of the kingdom. The abiding imminence of the kingdom gives us hope to persist and endure. Its transcendence guarantees its critical function with regard to all human structures, even while permeating those like the leaven.

As was already indicated, the gospel of Matthew was written to help a church in need of rediscovering its identity. Matthew's kingdom message was not a full answer to that need, but it exposes its very core. Like the writers of the two other synoptic gospels, he stressed certain features of the kingdom, which he knew were essential for his purpose. Thus, he himself, as the scribe who became a pupil in the kingdom of heaven, found things both old and new in the kingdom treasure box (13:52 - see Hagner 1998), and could present these "jewels" to his readers.

We have seen, that Matthew believed it necessary to put special emphasis on the necessity of obeying the kingdom demand, that is, of a life-style portraying the righteousness which the king expects of his 
people. It could be said that many Christians, especially in the western world, are not impressed by the track record of the church. They are tired of mere words. At this stage, they need to see a convincing alternative. This could be provided by the attractive "being" of Christians in the world; by a life-style of "righteousness" which portrays the transforming power of god, working through his spirit.

In our own country, several of the traditionally mainstream churches have lost their credibility as a result of their ideological and moral support to apartheid. Especially these churches would have to give serious thought to Matthew's message about the radical demand of the kingdom. Of course they should continue preaching the good news to all nations, but their credibility would only be restored by a really convincing life-style which exhibits the "exceeding righteousness", the essence of which is the manifestation of the boundless love of god in all spheres of life.

\section{Consulted literature}

Balch, D L (ed) 1991. Social history of the Matthean community. Cross-disciplinary approaches. Minneapolis: Fortress.

Combrink, H J B 1983. The Gospel according to Matthew: Introduction and Theology, in: du Toit, A B (ed), Guide to the New Testament iv. Pretoria: NG Kerkboekhandel, 57-101.

Cullmann, O 1948. Christus und die zeit. Die urchristliche zeit- und geschichtsauffassung. Zollikon-Zürich: Evangelischer verlag.

-, 1965. Heil als geschichte. Heilsgeschichtliche existenz im Neuen Testament. Tübingen: J.C.B. Mohr (Paul Siebeck).

De Villiers, P G R 1998. Messianism, in: du Toit, A B (ed), guide to the new testament 2: the new testament milieu. Halfway House: Orion, 454-457.

Dodd, C H 1963 (1935). Parables of the Kingdom. Rev. ed. $2^{\text {nd }}$ impr. London Glasgow: Fontana Books.

Duling, D C 1992. Kingdom of God, Kingdom of Heaven, in: Freedman, D N (ed), The Anchor Bible Dictionary 4. New York-London etc: Doubleday, 49-69.

$\mathrm{Du}$ Toit, A B 1966. The nature of the witness of the church in the world according to Mt 5:13-16, in: van Zyl, A H (ed), Biblical Essays 1966. Potchefstroom: Old and New Testament Societies of South Africa, 200-218.

,- 1977. Analysis of the structure of Mt 4:23-5:48. Neotestamentica 11, 32-47.

-, 1981. Die geloofwaardigheid van die kerk en sy boodskap, NGTT 32, 174.

Hagner, D 1998. New things from the scribe's treasure box, Expository Times 109, 329-334.

Jeremias, J 1971. Neutestamentliche theologie i: die verkündigung Jesu. Gütersloh: Gütersloher Verlagshaus Gerd Mohn.

Johnson, L T 1986. The writings of the New Testament. An interpretation. London: SCM Press. 
Joubert, S J 1993. Meestersimbool van 'n nuwe werklikheid: Jesus van Nasaret en die Koninkryk van God volgens die Sinoptiese Evangelies, In die Skriflig 27, 91 107.

Kingsbury, J D 1969. The parables of Jesus in Matthew 13. London: SPCK.

-, 1975. Matthew: Structure, Christology, Kingdom. Philadelphia: Fortress.

Kuhn, K G 1933. Malkut shamaim in der rabbinischen literatur, in: Kittel, G. (hrsg), Theologisches Wörterbuch zum Neuen Testament i. Stuttgart: Kohlhammer, 570573.

Lindemann, A 1986. Herrschaft gottes/reich gottes iv, in: Müller, G (hrsg), Theologische realenzyklopädie xv. Berlin-New York: Walther de Gruyter, 196-218.

Lippert, P 1968. Leben als zeugnis. Die werbende kraft christlicher lebensführung nach dem kirchenverständnis neutestamentlicher briefe. Stuttgart: Katholisches Bibelwerk (sbm 4).

Louw, J P \& Nida, E A 1988. Greek-English lexicon of the New Testament based on semantic domains 1. New York: United Bible Societies.

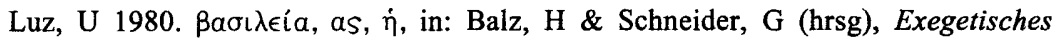
wörterbuch zum Neuen Testament i. Stuttgart-Berlin usw: verlag Kohlhammer, col. 481-491.

-, 1985. Das evangelium nach Matthäus (1-7). Zürich-Einsiedeln-Köln: Benziger; Neukirchen-Vluyn: Neukirchener verlag (ekk 1/1).

-, 1997. Das evangelium nach Matthäus (18-25). Zürich-Einsiedeln-Köln: Benziger; Neukirchen-vluyn: Neukirchener verlag (ekk 1/3).

Pamment, M 1981. Matthew and the kingdom of heaven, NTS 27, 211-232.

Ridderbos, H 1950. De komst van het koninkrijk. Jezus' prediking volgens de synoptische evangelien. Kampen: Kok.

Schäfer, R 1964. Das reich Gottes bei Albrecht Ritschl und Johannes weiss, Zeitschrift für Theologie und Kirche 61,68-88.

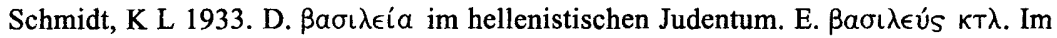
nt, in: Kittel, G (hrsg), Theologisches Wörterbuch zum Neuen Testament i. Stuttgart: Kohlhammer, 576-595.

Segal, A F 1991. Matthew's Jewish voice, in: Balch, D L (ed), 1991, 3-37.

Thomas, J C 1993. The Kingdom of God in the Gospel according to Matthew, NTS 39, 136-146.

Trilling, W 1964. Das wahre israel. Studien zur theologie des Matthäus-evangeliums. 3. Aufl. München: Kösel-verlag (sant 10).

Van der Walt, T 1962. Die koninkryk van God-naby! Kampen: Kok.

Weiss, J 1946 (1892). Die predigt Jesu vom reiche gottes. 3. Aufl. Göttingen: Vandenhoeck \& Ruprecht.

White, L M 1991. Crisis management and boundary maintenance: the social location of the Matthean community, in: Balch, D L (ed), 1991, 211-247. 